\title{
PERLINDUNGAN HUKUM ATAS KRIMINALISASI TERHADAP NOTARIS
}

\author{
Felix The, Endang Sri Kawuryan \\ Universitas Narotama | Jalan Klampis Semalang VII No.33, \\ Klampis Ngasem, Sukolilo, Surabaya \\ felixthe777@gmail.com
}

\begin{abstract}
The need for authentic deed making is increasing year by year in line with the proportional to the need for notary services. In carrying out his profession, the notary is required to be thorough and careful, given the notary's responsibility is very large and binding. Facts that currently occur in practice, it turns out not only the parties who become victim, but the notary is now often a victim of punishment. Therefore, a notary must obtain legal protection against him/her. Legal efforts must be pursued in order to achieve a truth and justice for a clean notary. Inconsistencies that occur in society and things that happen outside the rules of law becomes a gap to make a notary do a criminal act. The notary must play an active role as a good general official to anticipate and create an engagement in society especially in this globalization age. Therefore, the existence of applicable law must be able to provide a light for the notary profession.
\end{abstract}

Keywords: Penalization, notary public, globalization, crime

Abstrak: Kebutuhan dalam pembuatan akta autentik semakin meningkat tahun demi tahun, berbanding lurus dengan kebutuhan terhadap jasa notaris. Dalam menjalankan profesinya, notaris dituntut untuk teliti dan cermat, mengingat tanggung jawab notaris sangat besar dan bersifat mengikat. Fakta yang saat ini banyak terjadi di lapangan, ternyata tidak hanya para penghadap atau para pihak saja yang menjadi korban, akan tetapi notaris kini seringkali menjadi korban pemidanaan. Oleh karena itu, notaris harus mendapatkan perlindungan hukum atas dirinya. Upaya-upaya hukum harus ditempuh demi mencapai suatu kebenaran dan keadilan bagi notaris yang bersih. Inkonsistensi yang terjadi di masyarakat serta hal-hal yang terjadi di luar aturan hukum yang berlaku di masyarakat yang menjadi celah untuk menjadikan notaris melakukan perbuatan pidana. Notaris harus berperan aktif sebagai pejabat umum yang baik untuk mengantisipasi dan membuat suatu perikatan di masyarakat terutama di zaman globalisasi ini. Maka 
dari itu, eksistensi hukum yang berlaku harus dapat memberikan jalan terang bagi profesi notaris.

Kata Kunci: Pemidanaan, notaris, globalisasi, kejahatan

\section{Pendahuluan}

Memasuki zaman globalisasi, kebutuhan masyarakat semakin meningkat terutama dalam melakukan transaksi, antara lain transaksi jual beli, sewa-menyewa, dan lain-lain. Saat melakukan transaksi tersebut dibutuhkan akta autentik. Akta autentik tersebut mempunyai peranan hukum dalam mengatur transaksi yang terjadi dalam kehidupan masyarakat.

Kebutuhan hukum yang terus berkembang di masyarakat, menandakan kehidupan masyarakat yang juga bersifat dinamis. Hal ini berdampak pula pada peningkatan jasa Notaris. Notaris selaku pejabat umum, memberikan jasa hukum kepada masyarakat, dengan melihat pertimbangan Undang-Undang No 2 Tahun 2014 bahwa tujuan negara Indonesia adalah untuk menjamin kepastian, ketertiban, dan perlindungan hukum bagi setiap warga negaranya. Untuk menjamin kepastian, ketertiban, dan perlindungan hukum tersebut dibutuhkan alat bukti tertulis yang bersifat autentik mengenai perbuatan, perjanjian, penetapan, dan peristiwa hukum yang dibuat di hadapan atau pejabat yang berwenang.

Hal tersebut belum didukung oleh Pemerintah selaku aparatur negara melalui undang-undang. Para penghadap (yang ingin membuat akta) umumnya menyalahkan notaris apabila haknya merasa terabaikan. Padahal, hal tersebut harus diselidiki terlebih dahulu asal usulnya, sebab notaris hanya menjalankan dan sebagai perantara dari para pihak. Karena kenyataannya, notaris yang menyimpan sertifikat atas kehendak para pihak, menjadi seorang tersangka atas tuduhan penggelapan.

Akta adalah perjanjian-perjanjian tertulis yang dibuat di hadapan notaris. Notaris/PPAT dalam menjalankan tugasnya membuat akta, mempunyai tanggung jawab terhadap akta yang dibuatnya tersebut. Hal itu dilakukan untuk merealisasikan 
keinginan dari para pihak yang menghadapnya. Pencapaian atau hasil dari akta tersebut tidak terlepas dari iktikad dari para pihak yang membuatnya. Tujuan adanya akta autentik adalah sebagai alat bukti yang kuat pada saat menjadi bukti di pengadilan. Oleh sebab itu, akta autentik sangat dibutuhkan dan sangat disarankan pada saat pembuatan perjanjian. Dengan demikian, perjanjian tersebut mempunyai kekuatan pembuktian yang sah dan mengikat bagi para pihak.

Hasil dari pembuatan akta notaris/PPAT akan berbentuk akta autentik sesuai dengan Pasal 1868 KUHPerdata yang berbunyi akta autentik ialah suatu akta yang di dalam bentuk yang ditentukan oleh undang-undang, dibuat oleh atau di hadapan pegawai-pegawai umum yang berkuasa untuk itu di tempat di mana akta dibuatnya. Di dalam pembuatan akta autentik tersebut, notaris/PPAT dituntut untuk teliti dan cermat sesuai dengan data formil yang diberikan para penghadapnya, mengingat tanggung jawab notaris sangat besar dan bersifat mengikat selaku pejabat umum hingga seumur hidupnya.

Fakta di lapangan menunjukkan bahwa banyak notaris/PPAT yang dilaporkan dalam kasus pidana akibat pertanggungjawaban terhadap akta yang dibuatnya, diantaranya kasus Theresia Pontoh. Ia menjadi tersangka dalam kasus penipuan dan penggelapan yang ditangani oleh Polda Papua. Notaris Theresia Pontoh dituduh melanggar Pasal 372 KUHP tentang penggelapan. Kasus ini bermula dari laporan pada tanggal 9 Juli 2013, terkait dengan batalnya jual beli tanah antara Rudi Doomputra selaku calon pembeli dan Hengki Dawir sebagai pemilik tanah. Para pihak menghendaki Notaris Theresia Pontoh untuk membuatkan akta jual beli tanah SHM Nomor 02298 seluas 3.780 (Tiga ribu tujuh ratus delapan puluh) meter dan Nomor SHM 02299 seluas 7.424 (Tujuh ribu empat ratus dua puluh empat) meter, yang berlokasi di Jayapura.

Selanjutnya, dalam proses persyaratan pembuatan akta jual beli tanah tersebut karena belum terpenuhinya bukti PBB, Notaris 
Theresia Pontoh menangguhkan akta jual beli tanah tersebut dengan memberi tanda terima kepada Rudi Doomputra selaku pembeli. Penjual berubah pikiran dan ternyata tidak akan melakukan proses menjual kepada calon pembeli, dan calon pembeli mencari sertifikat tersebut kepada notaris. Notaris tidak mau memberikan sertifikat tersebut kepada pembeli karena memang belum terjadi peralihan hak. Karena hal tersebut, Theresia Pontoh dilaporkan atas dugaan penggelapan oleh pembeli karena menyimpan sertifikat dan tidak menyerahkan kepada calon pembeli tersebut. Kasus ini menjadikan Notaris Theresia oleh penyidik Polda Jayapura ditetapkan sebagai tersangka atas dugaan penggelapan karena menyimpan sertifikat tersebut. Theresia tetap ditahan hingga tingkat Mahkamah Agung.

Berdasarkan kasus dan uraian di atas, maka dalam artikel ini penulis akan mengkaji permasalahan terkait dengan notaris khususnya terkait dengan penegakan hukum atas kriminalisasi terhadap notaris.

\section{Pertanggungjawaban Notaris/PPAT dalam Pembuatan Akta}

Notaris merupakan pejabat umum yang berwenang untuk membuat akta autentik/otentik dan memiliki kewenangan lainnya sebagaimana dimaksud dalam Undang-Undang Nomor 2 Tahun 2014 tentang Perubahan atas Undang-Undang Nomor 30 Tahun 2004 tentang Jabatan Notaris (disebut UUJN) Pasal 1 angka 1.

Perjanjian-perjanjian akta yang dibuat oleh notaris mempunyai peranan penting dalam menciptakan kepastian hukum di dalam setiap hubungan hukum, sebab akta notaris bersifat autentik, dan merupakan alat bukti terkuat dan terpenuhi dalam setiap perkara yang terkait dengan akta notaris tersebut. ${ }^{1}$

Sjaifurrachman mengemukakan bahwa pentingnya peran notaris juga dapat dilihat dari kapasitasnya dalam memberikan legal advice, dan melakukan verifikasi terhadap sebuah perjanjian,

I Sjaifurrachman, Aspek Pertanggungjawaban Notaris dalam Pembuatan Akta, (Bandung: Mandar Maju, 20II), 7 . 
dengan melihat apakah sebuah perjanjian telah dibuat sesuai dengan kaidah pembuatan perjanjian yang benar dan tidak merugikan salah satu pihak atau perjanjian tersebut dibuat dengan tidak memenuhi syarat. Sebaliknya apabila tugas dan wewenang yang diberikan oleh negara kepada notaris tidak dilaksanakan dengan sebaik-baiknya dan setepat-tepatnya, maka kekeliruan dan penyalahgunaan yang dilakukan oleh notaris dapat menimbulkan terganggunya kepastian hukum dan rasa keadilan masyarakat. ${ }^{2}$ Berdasarkan penjelasan tersebut, menegaskan bahwa pentingnya akta notaris adalah untuk menghindari tidak sahnya suatu pembuatan akta. Pembuatan akta autentik tertentu, ada yang diharuskan oleh peraturan perundang-undangan dalam rangka menciptakan kepastian, ketertiban, dan perlindungan hukum. ${ }^{3}$ Dalam pembuatan akta selain harus mematuhi peraturan perundang-undangan, juga mendengarkan dan memahami apa yang diinginkan oleh para pihak, agar apa yang menjadi tujuan dalam pembuatan perjanjian itu dapat tersampaikan dengan baik. Di samping itu, hak dan kewajiban para pihak juga dapat terlaksana dan terealisasi, bukan hanya sebatas perjanjian di atas kertas saja.

Notaris pada umumnya berprofesi juga sebagai Pejabat Pembuat Akta Tanah (PPAT) karena tugas PPAT merupakan sebagian dari tugas yang dapat dilaksanakan oleh notaris. PPAT adalah pejabat yang ditunjuk dan diangkat oleh Pemerintah untuk menjadi partner mendampingi Badan Pertanahan Nasional (BPN) sebagai Mitra BPN. ${ }^{4}$

Andi Prajitno, mengemukakan tentang PPAT sebagai berikut: 5

"PPAT diangkat bukan untuk kepentingan pribadi PPAT itu sendiri tetapi untuk membantu Pemerintah sesuai dengan

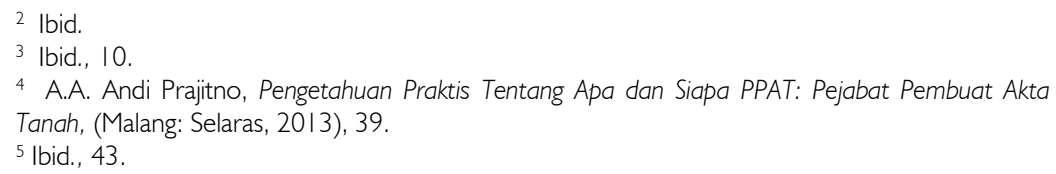


ketentuan mengenai pertanahan, sebagaimana diatur dan diuraikan secara rinci dalam ketentuan yang merupakan penjabaran dari PP No. 37 Tahun 1998 dan tindak lanjut dari ketentuan yang diatur dalam PP No. 24 tahun 1997, Permenag/KBPN Nomor 3 Tahun 1997, UURS yang menjelaskan tugas pokok dan kewenangan PPAT, yakni, pembuatan akta autentik sebagai bukti telah dilakukan perbuatan hukum tertentu mengenai hak atas tanah atau Hak Milik Atas Satuan Rumah Susun yang dijadikan dasar bagi pendaftaran perubahan data pendaftaran tanah yang diakibatkan oleh perbuatan hukum itu".

Pada dasarnya tugas PPAT dalam pendaftaran tanah adalah membantu Kepala Kantor Pertanahan Kabupaten/Kota dalam mewujudkan salah satu tujuan pendaftaran tanah sebagaimana ditetapkan dalam Pasal 3 Peraturan Pemerintah No. 24 Tahun 1997, yaitu untuk terwujudnya tertib administrasi pertanahan. ${ }^{6}$ Tugas dan Fungsi PPAT merupakan sebagian dari tugas dan fungsi notaris, artinya tugas dan kewenangan PPAT dapat dijalankan oleh notaris dengan bentuk akta yang diatur oleh Undang-Undang Jabatan Notaris (selanjutnya disingkat UUJN). PPAT tidak dapat melakukan pembuatan akta seketika itu juga ketika para pihak berkeinginan untuk dibuatkan akta tersebut. PPAT harus melakukan prosedur-prosedur sebelum akta dibuat.

Kewenangan PPAT dalam rangka pembuatan dan pengesahan akta autentik atas perbuatan hukum terhadap hak atas tanah tertentu yang menjadi dasar pencatatan pendaftaran, dan merupakan sebagian dari kegiatan pendaftaran tanah terhadap 8 (delapan) jenis akta PPAT yang menjadi alat bukti dan dasar perubahan data pendaftaran tanah (Pasal 95 ayat 1 Peraturan Menteri Negara Agraria//KBPN Permenag/KBPN Nomor 1 Tahun 2006 Jo. Pasal 2 ayat 2 Peraturan KBPN Nomor 1 Tahun 2006. ${ }^{7}$ Mengingat bahwa dalam Pasal 55 Peraturan Kepala Badan Pertanahan Nasional No 1 Tahun 2006 (Perkaban), menentukan

6 Urip Santoso, Pendaftaran dan Peralihan Hak atas Tanah, (Jakarta: Prenada Media Group, 2015), 344.

7 Andi Prajitno, Pengetahuan Praktis tentang Apa \& Siapa PPAT, 45. 
bahwa PPAT bertanggung jawab secara pribadi atas pelaksanaan tugas dan jabatannya dalam setiap pembuatan akta.

Adapun tanggung jawab PPAT pada pasal 54 Peraturan Kepala Badan Pertanahan Nasional sebagai berikut:

(1) Sebelum pembuatan akta mengenai perbuatan hukum sebagaimana dimaksud dalam Pasal 2 huruf a sampai dengan huruf g, PPAT wajib melakukan pemeriksaan kesesuaian/keabsahan sertifikat dan catatan lain pada Kantor Pertanahan setempat dengan menjelaskan maksud dan tujuannya.

(2) Dalam pembuatan akta sebagaimana dimaksud pada ayat (1), PPAT tidak diperbolehkan memuat kata-kata "sesuai atau menurut keterangan para pihak" kecuali didukung oleh data formil.

(3) PPAT berwenang menolak pembuatan akta, yang tidak didasari data formil.

(4) PPAT tidak diperbolehkan membuat akta sebagaimana dimaksud dalam Pasal 2 huruf a sampai dengan huruf g, atas sebagian bidang tanah yang sudah terdaftar atau tanah milik adat, sebelum diukur oleh Kantor Pertanahan dan diberikan Nomor Identifikasi Bidang Tanah (NIB).

Berdasarkan ketentuan Pasal 39 ayat (1) Peraturan Pemerintah No. 24 Tahun 1997, PPAT berwenang menolak untuk membuat akta jual beli, jika:

a. Mengenai bidang tanah yang sudah terdaftar, kepadanya tidak disampaikan sertifikat asli hak atas tanah yang bersangkutan atau sertifikat tidak sesuai dengan daftar-daftar yang ada di Kantor Pertanahan Kebupaten/Kota.

b. Salah satu atau para pihak yang akan melakukan jual beli atau saksinya tidak berhak atau memenuhi syarat untuk bertindak dalam jual beli.

c. Salah satu atau para pihak bertindak atas dasar surat kuasa mutlak yang pada hakikatnya berisikan perbuatan hukum pemindahan hak. 
d. Untuk jual beli yang akan dilakukan belum diperoleh izin pejabat atau instansi yang berwenang, apabila izin tersebut diperlukan menurut peraturan perundang-undangan yang berlaku.

e. Objek jual beli yang bersangkutan sedang dalam sengketa mengenai data fisik dan/atau data yuridis, dan

f. Tidak dipenuhinya syarat lain atau dilanggar larangan yang ditentukan dalam peraturan perundang-undangan yang berlaku.

Dalam pembuatan akta, PPAT wajib mencantumkan NIB (Nomor Identifikasi Bidang) dan atau nomor hak atas tanah, nomor Surat Pemberitahuan Pajak Terhutang (SPPT) PBB, penggunaan dan pemanfaatan tanah sesuai dengan keadaan lapangan. Hal ini membuktikan bahwa tindakan seorang notaris dalam melaksanakan tugas dan tanggung jawabnya diawasi oleh Majelis Pengawas. Notaris dalam menjalankan jabatannya, tidak lepas dari tanggung gugat. Tanggung gugat terhadap notaris timbul karena adanya kesalahan yang dilakukan saat menjalankan tugas jabatan dan kesalahan itu menimbulkan kerugian bagi orang yang minta jasa notaris atau biasa disebut klien. ${ }^{8}$

Notaris, sebagai pejabat umum yang diberi kewenangan untuk membuat akta autentik, mempunyai konsekuensi untuk bertanggung jawab apabila terjadi penyimpangan ataupun adanya pelanggaran persyaratan dalam pembuatan akta, sebab perbuatan notaris tersebut akan menimbulkan akibat terhadap sah atau tidaknya akta yang dibuat oleh notaris tersebut.

Sjaifurrachman dengan Habib Adjie memaparkan tentang pembuatan akta yang cacat hukum yang isinya bahwa: ${ }^{9}$

“Apabila akta autentik dalam pembuatannya cacat hukum yang semata-mata disebabkan oleh kesalahan dari notaris dan kemudian akta itu oleh Pengadilan dinyatakan tidak autentik, tidak sah, atau menjadi batal demi hukum atau terdegradasi

\footnotetext{
${ }^{8}$ Sjaifurrachman, Aspek Pertanggungjawaban Notaris..., 16.

${ }^{9}$ lbid., 17.
} 
menjadi akta di bawah tangan, maka notaris yang bersangkutan harus bertanggung gugat atas kesalahan yang ditimbulkan karena kecerobohannya."

Ada tiga unsur utama agar suatu akta autentik dapat terwujud, yaitu:

1. Bentuk akta autentik harus ditentukan oleh Undang-Undang;

2. Dibuat oleh atau di hadapan pejabat umum;

3. Akta tersebut dibuat oleh atau di hadapan pejabat umum dalam wilayah jabatan kewenangannya.

Ditinjau dari berbagai aspek tersebut, kita dapat melihat bahwa pada hakikatnya, seorang notaris harus selalu memperhatikan asas kehati-hatian dan asas kecermatan dalam melaksanakan jabatannya karena pertanggungjawaban notaris terus berlanjut meskipun ia telah pensiun.

Dilihat dari segi Hukum Perdata, apabila notaris yang melalaikan kewajiban hukum sebagaimana yang seharusnya dilakukan, atau dalam hal notaris telah wanprestasi terhadap klien sebagaimana diatur di dalam ketentuan Pasal 1243 KUH Perdata, dan/atau telah melakukan perbuatan melawan hukum Pasal 1365 KUH Perdata, ${ }^{10}$ maka notaris menyebabkan kerugian kepada klien yang ditanganinya.

Terkait dengan tanggung jawab notaris, Habib Adjie menjelaskan bahwa: ${ }^{11}$

“Notaris bukan pihak dalam akta, karena kewajiban menurut UUJN dan UUJN-P dalam setiap akta harus ada nama notaris, karena akta tersebut merupakan kehendak para pihak, tanpa adanya kehendak para pihak yang meminta kepada notaris untuk membuat akta, maka notaris tidak bisa membuat akta apapun, sehingga jika para penghadap dan pihak lainnya yang bukan penghadap mempersoalkan akta tersebut, tidak perlu menarik notaris sebagai Tergugat ataupun Penggugat".

Mengenai bentuk tanggung jawab notaris, Abdulkadie

10 Ibid., 18.

I Habib Adjie, Penafsiran Tematik Hukum Notaris Indonesia, (Bandung: Refika Aditama, 20l5), 164. 
Muhammad mengatakan bahwa bentuk-bentuk tanggung jawab notaris dapat diberi pengertian sebagai berikut: ${ }^{12}$

1. Notaris dituntut melakukan pembuatan akta dengan baik dan benar, artinya akta yang dibuat itu memenuhi kehendak hukum dan permintaan pihak yang berkepentingan karena jabatannya.

2. Notaris dituntut menghasilkan akta yang bermutu, artinya akta yang dibuatnya itu sesuai dengan aturan hukum dan kehendak pihak yang berkepentingan dalam arti sebenarnya bukan mengada-ada.

3. Berdampak positif, artinya siapapun akan mengakui akta notaris itu mempunyai kekuatan bukti sempurna.

Perlindungan Hukum terkait Pertanggungjawaban PPAT dalam Jabatannya dan Kebatalan Akta

Ada beberapa hal yang perlu diingat dalam pembuatan akta notaris. Notaris hanya mendasarkan pembuatan akta pada kebenaran dokumen saja atau kebenaran formal. ${ }^{13}$ Kebenaran formal yang dimaksud adalah dalam pembuatan akta, notaris hanya menetapkan seperti apa yang dilihat, didengar, atau apa yang dialami sendiri sesuai dengan apa yang diberitahukan atau disampaikan oleh para pihak kepada notaris, baik berupa keterangan-keterangan maupun dokumen-dokumen hukum lainnya seperti Kartu Tanda Penduduk, Kartu Keluarga, dan sertifikat-sertifikat lainnya.

Menurut Moelyatno, pertanggungjawaban pidana dinamakan criminal liability atau responsibility untuk dapat dipidananya seseorang, selain melakukan perbuatan pidana, orang itu juga harus mempunyai kesalahan.

Unsur kesalahan dalam arti luas yaitu:

1. Dapat dipertanggungjawabkan pembuat;

2. Adanya kaitan psikis antara pembuat dan perbuatan, yaitu

12 Sjaifurrachman, Aspek Pertanggungjawaban Notaris..., 19.

13 Ibid., 27. 
adanya sengaja atau kesalahan dalam arti sempit (culpa).

3. Tidak adanya dasar peniadaan pidana yang dapat menghapus dipertanggungjawabkannya.

Selanjutnya mengenai kemampuan bertanggung jawab secara teoritis harus memenuhi unsur yang terdiri atas:

1. Kemampuan untuk membeda-bedakan antara perbuatan yang baik dan yang buruk, yang sesuai hukum dan yang melawan hukum.

2. Kemampuan untuk menentukan kehendaknya menurut keinsyafan tentang baik dan buruknya perbuatan tadi. ${ }^{14}$

Di dalam menjalankan tugas dan kewenangannya tersebut, notaris harus selalu memperhatikan undang-undang, agar tidak terjadi saling pertentangan antara aturan yang satu dengan yang lain. Pelaksanaan jabatan notaris secara de facto tidak bisa lepas dari para penegak hukum. Apa yang dilakukan notaris kerapkali bertabrakan dan bertentangan dengan penegak hukum, sehingga tidak jarang notaris juga terbentur pada pelaksanaan normanorma hukum yang digunakan oleh para oknum itu sendiri dengan sedikit penyelewengan dan pengisian dari celah hukum. Oleh sebab itu, penegakan hukum di Indonesia dalam praktiknya masih dirasa agak meragukan meskipun secara normatif aturan yang diberikan sudah sangat baik. Terkadang para penegak hukum masih runcing ke atas dan tumpul ke bawah.

Menurut Romli Atmasasmita, peraturan perundangundangan secara umum belum dapat menjamin pelaksanaan penegakan hukum secara efektif. Hal ini disebabkan oleh lima faktor yaitu: Pertama, substansi peraturan perundang-undangan kurang lengkap dan masih ada kelemahan-kelemahan; Kedua, substansi peraturan perundang-undangan tumpang tindih satu sama lain; Ketiga, ada substansi peraturan perundang-undangan yang masih menempatkan kepentingan pemerintah terlalu besar melebihi kepentingan masyarakat luas; Keempat, masih belum ada

14 Ibid., 33. 
ketegasan mengenai perbedaan antara fungsi eksekutif, yudikatif, dan legislatif; Kelima, kesadaran dan tanggung jawab berbangsa dan bernegara dalam menghasilkan produk peraturan perundangundangan dalam penegakan hukum masih lemah. ${ }^{15}$

Analogi dalam Undang-Undang Hukum Pidana Jerman, hingga ayat pertama dari paragraf kedua kitab Undang-undang Hukum Pidana Jerman itu kemudian berbunyi: "Bestraft wird, wer eine Tat begeht, die das Gesetz fur strafbar erklaet oder die nach dem Grundgedanken eines Strafgesetzes und nach gesundem Volksempfinden Bestraffung verdient"16 yang artinya: dapat dihukum barang siapa yang melakukan suatu perbuatan yang oleh undang-undang telah dinyatakan sebagai perbuatan yang terlarang atau yang menurut asas-asas suatu Undang-Undang Pidana dan menurut kesadaran hukum yang sehat dari rakyat dipandang sebagai patut dihukum.

Cacatnya akta notaris dapat menimbulkan batalnya bagi suatu akta notaris. Ditinjau dari saksi atau akibat hukum dari kebatalan dapat dibedakan menjadi:

1. Batal demi hukum / van rechtswege nietig.

2. Dapat dibatalkan / vernietigbaar.

3. Non existent.

Sesuai Pasal 84 UUJN, bahwa tindakan pelanggaran yang dilakukan notaris terhadap ketentuan sebagaimana dimaksud dalam Pasal 16 ayat (1) huruf i, Pasal 16 ayat (1) huruf k, Pasal 41, Pasal 44, Pasal 48, Pasal 49, Pasal 50, Pasal 51, atau Pasal 52 yang mengakibatkan suatu akta hanya mempunyai kekuatan pembuktian sebagai akta di bawah tangan atau suatu akta menjadi batal demi hukum dapat menjadi alasan bagi pihak yang menderita kerugian untuk menuntut penggantian biaya, ganti rugi, dan bunga kepada notaris.

Penilaian terhadap akta notaris harus dilakukan dengan Asas Praduga Sah atau disebut Vermoeden wan Rechmatigheid atau

15 Ibid., 47.

${ }^{16}$ Pompe dalam P.A.F. Lamintang, Dasar-Dasar Hukum Pidana di Indonesia, (Jakarta: Sinar Grafika, 2014), 82. 
Presumptio Iustae Causa, yaitu akta Notaris harus dianggap sah sampai ada pihak yang menyatakan akta tersebut tidak sah. Oleh sebab itu, seorang notaris dalam membuat akta harus sesuai dengan peraturan perundang-undangan, dan penuh tanggung jawab terhadap isi akta yang dibuatnya sehingga klien dan notaris sama-sama mendapatkan kepastian hukum, mengingat notaris adalah lembaga kepercayaan masyarakat demi untuk melindungi masyarakat dengan selalu menganut pada asas kehati-hatian agar tidak terjadi kesalahan.

\section{Kronologi Kasus Notaris Theresia Pontoh ${ }^{17}$}

Pada tanggal 29 Maret 2011, seorang pemilik tanah bernama Hengki Dawir (asli Papua) selaku calon penjual, dan calon pembeli tanah bernama Rudy Doom Putra (Tionghoa Surabaya), datang bersama-sama menghadap ke Notaris Theresia Pontoh di kantornya untuk meminta dibuatkan Akta Jual Beli (AJB) tanah. Hengki Dawir pada saat itu membawa 2 (dua) sertifikat tanah atas namanya. Ketika itu, para pihak menginginkan untuk dibuatkan akta jual beli tanah SHM Nomor 02298 seluas 3.780 meter dan Nomor SHM 02229 seluas 7.424 meter, yang berlokasi di Jayapura. Akan tetapi, karena persyaratan yang belum lengkap, maka Notaris Theresia Pontoh tidak melanjutkan pembuatan Akta Jual Beli tersebut dan dibuatkanlah tanda terima atas nama Rudy Doom Putra selaku calon pembeli sesuai dengan keinginan Rudy Doom Putra dan kemauan itu diikuti oleh Hengki Dawir selaku calon penjual. Pada saat itu masih belum dilengkapi persyaratan pembuatan AJB/Balik Nama seperti Akta Nikah, KK, PBB, NPWP, bukti kwitansi.

Ketika itu, Theresia Pontoh tidak menerbitkan Akta Jual Beli, tidak menerima uang honorarium PPAT dan tidak menerima titipan pajak BPHTB dan pajak SSP serta tidak menyuruh dan menyaksikan bayar-membayar antara Rudy Doom dengan Hengki

17 Syafran Sofyan, "Kronologi Singkat Permasalahan Kasus Rekan Theresia Pontoh", Notary Public, diakses dari http://www.notary.my.id/20 I 4/I 0/kronologis-singkat-permasalahan-kasus.html, pada tanggal 8 Januari 2017 pukul 09.58. 
Dawir. Hanya diberikan fotocopy kwitansi pembayaran uang muka, antara Hengki Dawir dan Rudy Doom Putra sebesar Rp 500 juta.

Lalu pada tanggal 30 Maret 2011, Hengki Dawir datang ke kantor Notaris Theresia Pontoh untuk mengambil 2 (dua) sertifikat tersebut. Akan tetapi, Theresia tidak mau memberikannya dengan alasan bahwa Hengki Dawir harus datang bersama-sama dengan Rudy Doom Putra karena pada saat menyerahkan sertifikat itu Hengki Dawir dan Rudy Doom Putra hadir bersama-sama. Pada hari tersebut pula, Hengki Dawir memberikan surat ke Notaris Theresia Pontoh untuk tidak melanjutkan proses jual beli karena 2 (dua) sertifikat tersebut sudah dijual sebelumnya oleh Hengki Dawir kepada "S" dalam bentuk tanah hak ulayat dan "S" yang membiayai hingga terbit sertifikat tersebut. " $\mathrm{S}$ " juga memberikan surat untuk tidak melanjutkan proses AJB disertai dengan buktibukti kwitansi pembelian yang telah dibayar dan diterima Hengki Dawir.

Pada tanggal 26 April 2011, Theresia Pontoh meminta Hengki Dawir, Rudy Doom Putra dan "S" untuk datang ke kantor Theresia guna mencari solusi atas permasalahan 2 (dua) sertifikat tersebut. Rudy Doom Putra membujuk "S" agar bisa memiliki 2 (dua) sertifikat tersebut, tapi "S" tidak mau dengan alasan bahwa Rudy Doom Putra sejak awal sudah mengetahui betul tanah 2 (dua) sertifikat tersebut telah dibeli oleh " $\mathrm{S}$ " dan "S" yang mengurus penerbitan 2 (dua) sertifikat tersebut dan yang menimbun tanah 2 sertifikat tersebut.

Pada saat sertifikat telah terbit dan bisa diambil dari BPN, kenapa justru Rudy Doom Putra memaksa Hengki Dawir untuk mengambil di Badan Pertanahan Nasional (BPN), akan tetapi fisik 2 (dua) sertifikat dipegang oleh staff Rudy Doom Putra dan Hengki Dawir hanya menandatangani buku ekspedisi pengambilan sertifikat di BPN, dan Rudy Doom Putra memaksa Hengki Dawir langsung ke kantor Theresia Pontoh. Oleh karena tidak ada kesepakatan di antara Hengki Dawir, Rudy Doom Putra 
dan "S", maka Theresia Pontoh tidak menyerahkan 2 (dua) sertifikat tersebut dan menyarankan untuk meminta penetapan Pengadilan Negeri agar 2 (dua) sertifikat tersebut diserahkan kepada orang yang tepat.

Selanjutnya pada bulan Mei 2011, Rudy Doom Putra selaku calon pembeli melaporkan Notaris Theresia Pontoh ke Polresta Jayapura dengan Pasal 335 KUHP, tetapi kasus itu dihentikan dengan Surat Perintah Penghentian Penyidikan (SP3) karena tidak cukup unsur dan tidak cukup bukti.

Pada tanggal 1 Juni 2011, Hengki Dawir selaku calon penjual, melakukan gugatan Theresia Pontoh secara perdata pada tanggal 1 Juni 2011 dan berakhir dengan perdamaian, dikuatkan dengan Putusan Pengadilan atas Akta Perdamaian (akta van Dading) dengan Nomor 56/Pdt.G/2010/PN Jayapura.

Pada tanggal 10 Agustus 2011, akhirnya kedua sertifikat tersebut, yang masih tetap bernama Hengki Dawir dikembalikan kepada Hengki Dawir selaku pemiliknya dengan tanda terima penyerahan sertifikat.

Namun pada bulan September 2011, Rudy Doom Putra menggugat Notaris Theresia secara perdata pada September 2011 dan Rudy Doom Putra mencabut gugatan disebabkan Hengki Dawir meninggal dunia pada pertengahan sidang.

Pada tanggal 9 Juli 2013, Rudy Doom Putra melaporkan Notaris Theresia Pontoh dengan pasal 372 KUHP tentang Penggelapan. Padahal 2 (dua) sertifikat tersebut sudah tidak dalam penguasaan Notaris Theresia Pontoh dengan melaksanakan isi dari Putusan Pengadilan Negeri Jayapura (akta van Dading). Akan tetapi, Notaris Theresia Pontoh ditetapkan sebagai tersangka.

Pada tanggal 20 November 2013, keluar surat keterangan dari organisasi Notaris dengan Nomor 49/PP-IPPAT/XI/2013, yang intinya Notaris Theresia telah bekerja dengan benar, tidak melakukan kesalahan apapun dan bekerja sesuai dengan prosedur.

Pada tanggal 23 Juli 2014, Notaris Theresia ditahan Lapas Abepura dengan dijemput paksa oleh Tim Polda Papua. Pada 
tanggal 20 Agustus 2014, semua berkas Notaris Theresia dinyatakan P21 dan dilimpahkan ke Pengadilan Negeri Jayapura.

Vonis penjara 1 tahun 6 bulan sudah diputuskan pada sidang Putusan Terdakwa Kasus Penggelapan Tanah seluas 1 hektar oleh Theresia Pontoh. Sidang putusan tersebut terjadi pada hari Sabtu, tanggal 19 September 2015 di Pengadilan Negeri kelas 2A Abepura Jayapura. Akhirnya terdakwa Theresia Pontoh akibat perbuatan hukumnya dijerat Pasal 374 KUHP tentang penggelapan dan dijatuhi hukuman 1 tahun 6 bulan penjara.

\section{Kasus Notaris Theresia Pontoh dan Perlindungan Hukumnya}

Melihat kronologi kasus Theresia Pontoh di atas, dapat diketahui bahwa adakalanya masalah timbul bukan dari kesalahan notaris, namun karena adanya iktikad tidak baik dari para pihak. Keputusan Penyidik yang menjadikan notaris sebagai tersangka, menunjukkan bahwa notaris sebagai pejabat umum tidak kebal terhadap hukum. Notaris yang selain tugasnya memberikan jaminan serta perlindungan hukum terhadap pelaksanaan tugas dan kewajiban dari jabatannya, namun kenyataannya malah menjadi seorang tersangka. Oleh karena itu, seorang notaris juga butuh akan adanya perlindungan hukum terhadap dirinya, tidak hanya perlindungan hukum terhadap para pihak.

Berdasarkan kasus di atas, sebenarnya notaris telah menjalankan tugas dan tanggung jawabnya selaku notaris yang baik. Notaris Theresia Pontoh telah menjalankan tugas dan jabatannya dengan benar. Ia menyimpan sertifikat tersebut bukan berarti untuk menggelapkan sertifikat, tetapi untuk mempertanggungjawabkannya dengan pihak calon pembeli, mengingat bahwa penjual dan calon pembeli datang bersamasama, dan atas kesepakatan bersama untuk memberi tanda terima atas nama pembeli, dan sesuai kesepakatan awal dikarenakan penyerahan dilakukan secara bersama-sama, maka untuk mengambil sertifikat yang dititipkan tersebut harus juga dilakukan dengan bersama-sama. 
Dalam hal ini. yang mempunyai iktikad tidak baik ialah penjual yaitu Hengki Dawir. Ia telah menjual kepada "S" dengan hak ulayat, namun setelah terbitnya sertifikat, yang justru dibiayai oleh S, malah Hengki Dawir selaku penjual akan menjual tanah tersebut kepada Rudy Doom Putra. Hal ini menunjukkan bahwa Hengki Dawir telah ada iktikad yang tidak baik. Notaris telah menjalankan tugas dengan asas kecermatan. Hal tersebut sebetulnya tidak menimbulkan kerugian apapun kepada Rudy Doom Putra selaku pembeli, sebab yang akan membatalkan akta jual beli tersebut adalah Hengki Dawir selaku penjual. Apabila segala surat-surat memang belum dilengkapi, PPAT wajib untuk meminta terlebih dahulu agar segala surat-surat yang dibutuhkan untuk pembuatan Akta Jual Beli untuk dilengkapi terlebih dahulu, sesuai dengan Pasal 38, PP No 24 Tahun 1997 tentang Pendaftaran Tanah.

Faktanya, Notaris Theresia Pontoh divonis oleh hakim Pengadilan Negeri dengan Vonis penjara 1 tahun 6 bulan. Hukuman ini sebenarnya tidak tepat untuk diterapkan terhadap Notaris/PPAT Theresia, karena ia hanya menjalankan tugas dan tanggung jawabnya selaku notaris. Sesuai dengan Pasal 50 KUHP, "Barangsiapa melakukan perbuatan untuk melaksanakan ketentuan undang-undang, tidak dipidana." Di dalam bidang hukum pidana, seseorang dapat dijatuhkan sanksi pidana apabila memenuhi beberapa unsur, yaitu: ${ }^{18}$

1. Mampu bertanggung jawab.

2. Sengaja atau alpa.

3. Tidak ada alasan pemaaf.

Dalam hal ini, Theresia menjalankan asas kehati-hatian selaku Notaris/PPAT. Para penghadap yang awalnya menitipkan Sertifikat Tanah tersebut secara bersama-sama, oleh sebab itu sudah seyogyanya, apabila salah satu pihak ingin membatalkan dan ingin mengambil sertifikat, harus dilakukan secara bersama-

${ }^{18}$ E.Y Kanter dan S.R Sianturi, Asas-Asas Hukum Pidana di Indonesia dan Penerapannya, (Jakarta: AHM-PTHM, 1982), 166. 
sama pula, seperti pada saat melakukan penitipan sertifikat kepada notaris. Hal ini akan menunjukkan iktikad baik dari para pihak.

Notaris dalam hal ini telah sangat tepat menjalankan pertanggung-jawabannya, yaitu tidak memberikan sertifikat yang diminta oleh pembeli, karena memang transaksi belum dilakukan. Hal ini perlu dinilai adanya kriminalisasi terhadap Notaris Theresia Pontoh, sebab Ikatan Notaris Indonesia (INI) pun telah memberikan surat keterangan bahwa yang dilakukan oleh Notaris Theresia seluruhnya telah tepat dan sesuai prosedur.

Pasal yang dijeratkan kepada Notaris Theresia yakni, Pasal $374 \mathrm{KUHP}$, yang menentukan "Penggelapan yang dilakukan oleh orang yang penguasaannya terhadap barang disebabkan karena ada hubungan kerja atau karena pencarian atau karena mendapat upah untuk itu, diancam dengan pidana penjara paling lama lima tahun".

Ketika penghadap datang ke notaris agar tindakan atau perbuatannya diformulasikan ke dalam akta autentik sesuai dengan kewenangan notaris, dan kemudian notaris membuatkan akta atas permintaan atau keinginan para penghadap tersebut. Hal ini memberikan landasan kepada notaris dan para penghadap telah terjadi hubungan hukum. ${ }^{19}$ Oleh sebab itu, notaris harus menjamin bahwa akta yang dibuatnya tersebut telah sesuai menurut aturan hukum yang sudah ditentukan sehingga kepentingan yang bersangkutan terlindungi dengan akta tersebut.

Notaris bertanggung jawab apabila prosedur dan penerapan hukum terhadap para penghadap. Notaris bukanlah seorang pejabat yang dapat diperintah oleh para penghadap dalam pembuatan akta. Akta yang dibuat oleh notaris harus memenuhi syarat peraturan perundang-undangan, dan notaris mempunyai hak untuk menunda pembuatan akta, apabila syarat atau dokumen para penghadap belum terlengkapi.

${ }^{19}$ Habib Adjie, Menjalin Pemikiran-Pendapat tentang Kenotariatan, (Bandung: Citra Aditya Bakti, 2013), 113. 
Apabila Notaris Theresia Pontoh memaksakan proses pembuatan akta, padahal dokumen para penghadap masih belum lengkap, maka notaris dalam menjalankan jabatannya tidak cermat, tidak teliti, dan tidak tepat dalam menerapkan aturan hukum yang berkaitan dengan pelaksanaan tugas jabatan notaris berdasarkan UUJN dan juga dalam menerapkan aturan hukum yang berkaitan dengan isi akta.

Perbuatan yang dilakukan oleh Notaris Theresia telah tepat, namun ia mendapatkan kriminalisasi dari berbagai pihak. Seperti yang dikemukakan oleh John Arbuthnot, 17-th century, "Law is a Bottomless-Pit, it is a Cormorant", yang artinya Hukum adalah sesuatu yang tidak mempunyai batas, alias cakupannya luas sekali, dia adalah suatu makhluk rakus kejam, yang menelan apa saja. ${ }^{20}$

Penerapan hukum yang dilakukan oleh Notaris Theresia telah tepat. Ia menyimpan sertifikat tanah tersebut berdasarkan keinginan para pihak. Maka apabila pihak penjual ingin membatalkan kesepatakan dan ingin mengambil kembali sertifikat tanah tersebut, harus sesuai dengan persetujuan para pihak, bukan karena keinginan dan kehendak satu pihak semata.

Pemidanaan atas kriminalisasi terhadap Notaris Theresia, bahwa menurut William Blackstone pada 1723-1780,"Law is a rule of action prescribed or dictated by some superior which some inferior if bound to obey", yang artinya Hukum adalah suatu aturan tindakantindakan yang ditentukan oleh orang-orang yang berkuasa, bagi orang-orang yang dikuasai untuk ditaati..21

\section{Penutup}

PPAT tidak bisa dimintai pertanggungjawaban, karena transaksi jual-beli merupakan hasil kesepakatan para pihak yang telah disetujui oleh PPAT. PPAT bersifat mandiri dalam hal pembuatan akta, sebagaimana dikemukakan pada Pasal 39,

${ }^{20}$ John Arbuthnot dalam Achmad Ali, Menguak Teori Hukum (Legal Theory) dan Teori Peradilan (Judicial Prudence), (Jakarta: Kencana Prenada Media Group, 20 I3), 464.

${ }^{21}$ Ibid., 421 . 
Peraturan Pemerintah No 24 Tahun 1997. PPAT berhak untuk menolak pembuatan akta jika terjadi kurang memenuhi kelengkapan syarat dalam pembuatan akta.

Notaris dalam melaksanakan tugas dan tanggung jawabnya mendapatkan perlindungan hukum sesuai dengan peraturan perundang-undangan, yakni Pasal 50 KUHP. Terkait dengan kasus Theresia Pontoh dapat diambil kesimpulan bahwa penyimpanan sertifikat pada notaris bukanlah merupakan suatu tindak pidana. Notaris telah memberikan tanda terima pada saat penyerahan sertifikat kepada pembeli, dengan kesepakatan para pihak. Pembuatan akta berdasarkan ketentuan, 1320 ayat (1) BW menentukan bahwa syarat sahnya perjanjian karena kesepakatan para pihak, bukan dari notaris sebagai pejabat umum. Meskipun syarat sahnya perjanjian telah terpenuhi, namun apabila PPAT menyatakan bahwa syarat pembuatan akta belum terpenuhi oleh para pihak, maka PPAT berhak untuk menolak pembuatan akta tersebut.

\section{Daftar Pustaka}

Adjie, Habib. Menjalin Pemikiran-Pendapat tentang Kenotariatan. Bandung: Citra Aditya Bakti, 2013

------. Penafsiran Tematik Hukum Notaris Indonesia. Bandung: Refika Aditama, 2015

Ali, Achmad. Menguak Teori Hukum (Legal Theory) dan Teori Peradilan (Judicial Prudence). Jakarta: Kencana Prenada Media Group, 2013

Kanter, E.Y. dan S.R Sianturi. Asas-asas Hukum Pidana di Indonesia dan Penerapannya. Jakarta: AHM-PTHM, 1982

Lamintang, P.A.F. Dasar-Dasar Hukum Pidana di Indonesia. Jakarta: Sinar Grafika, 2014

Prajitno, A.A. Andi. Pengetahuan Praktis tentang Apa dan Siapa PPAT: Pejabat Pembuat Akta Tanah. Malang: Selaras, 2013

Santoso, Urip. Pendaftaran dan Peralihan Hak atas Tanah. Jakarta: Prenada Media Group, 2015 
Sjaifurrachman. Aspek Pertanggungjawaban Notaris dalam Pembuatan Akta. Bandung: Mandar Maju, 2011

Sofyan, Syafran. "Kronologi Singkat Permasalahan Kasus Rekan Theresia Pontoh", Notary Public, diakses dari http://www.notary.my.id/2014/10/kronologis-singkatpermasalahan-kasus.html, pada tanggal 8 Januari 2017 pukul 09.5

Kitab Undang-Undang Hukum Pidana

Kitab Undang-Undang Hukum Perdata

Undang-Undang No. 30 Tahun 2004 tentang Jabatan Notaris

Undang-Undang No. 2 Tahun 2014 tentang Perubahan Atas Undang-Undang No. 30 Tahun 2004 tentang Jabatan Notaris

Peraturan Pemerintah Republik Indonesia No. 24 Tahun 1997 tentang Pendaftaran Tanah.

Peraturan Pemerintah No 24 Tahun 2016 tentang Perubahan atas Peraturan Pemerintah Nomor 37 Tahun 1998 Tentang Peraturan Jabatan Pejabat Pembuat Akta Tanah.

Peraturan Pemerintah Nomor 37 Tahun 1998 tentang Peraturan Jabatan Pejabat Pembuat Akta Tanah.

Peraturan Menteri Negeri Agraria Nomor 3 Tahun 1997 